\title{
The Impact of Public R\&D Subsidies and Tax Incentives on Business R\&D Expenditures
}

Submitted 18/11/19, 1st revision 15/12/19, 2nd revision 25/01/20, accepted 09/02/20

\begin{abstract}
Dejan Ravšelj ${ }^{1}$, Aleksander Aristovnik ${ }^{2}$
Abstract:

Purpose: Private R\&D investment in the business sector is often subject to market failures, such as positive externalities, information asymmetries, uncertainty and risk, making it often less than socially desirable. This is the primary reason that governments promote private $R \& D$ investment. Accordingly, the main aim of this paper is to investigate the impact of public $R \& D$ policy on business $R \& D$ expenditures.
\end{abstract}

Design/methodology/approach: Applying panel data regression analysis on a sample of 3,113 company-year observations, covering Slovenian companies for the period 2012-2016.

Findings: The empirical results show that public support for $R \& D$ investment plays an important role in firms' $R \& D$ expenditures. As to $R \& D$ subsidies, the empirical results reveal they are generally ineffective since they displace firms' $R \& D$ expenditures. Yet they do become effective when used in combination with $R \& D$ tax incentives and received by companies that are growing. On the contrary, the empirical results also show that $R \& D$ tax incentives are always effective when companies have a sufficient tax base.

Practical Implications: The overall findings suggest that $R \& D$ tax incentives are more effective than $R \& D$ subsidies in Slovenia. However, $R \& D$ subsidies are still attractive especially for smaller companies without a sufficient tax base. It is hence important to consider both public policy instruments as two parallel ways of supporting firms' $R \& D$ expenditures.

Originality/value: Utilising a comprehensive dataset covering Slovenian companies made by merging multiple data sources, namely $R \& D$ survey, tax, balance-sheet and incomestatement data, representing the main originality and value of the paper.

Keywords: $R \& D$ subsidies, $R \& D$ tax incentives, $R \& D$ investment, Panel data regression analysis, Slovenia.

JEL Codes: H20, H25, O32.

Paper type: Research study.

Acknowledgments: The authors acknowledge the financial support from the Slovenian Research Agency (research core funding No. P5-0093).

\footnotetext{
${ }^{1}$ Faculty of Public Administration, University of Ljubljana, Ljubljana, Slovenia dejan.ravselj@fu.uni-lj.si.

${ }^{2}$ Corresponding author, Faculty of Public Administration, University of Ljubljana, Ljubljana, Slovenia, aleksander.aristovnik@fu.uni-lj.si.
} 


\section{Introduction}

The global economy is currently facing new challenges associated with globalisation, the emergence of new technologies, and the transition to a knowledgebased economy. This has resulted in fast-growing markets with ever-tougher global competition that is forcing companies to provide value-added products, processes and services. This has also affected companies' investment structure and the importance of certain types of investment (Ahuja, 2011). This explains why the role of $\mathrm{R} \& \mathrm{D}$ investment is becoming increasingly important since it is often seen as the key driver of innovative outcomes and keeping a competitive position in the market (Arkhipova et al., 2019; Akhmetshin et al., 2018; Dmitriev and Novikov, 2018). R\&D investment therefore is an important factor in the long-term viability of modern companies, especially in the conditions of an ever-changing business environment. Accordingly, companies should be motivated for R\&D investment in order to develop their competitive advantages (Ravšelj and Aristovnik, 2017; 2018; 2019).

The main aim of this paper is to answer the main research question of whether different public policy instruments for R\&D investment stimulate firms' R\&D spending. Namely, Slovenia may be seen as a natural environment for evaluating the impact of different forms of public support for R\&D investment on firms' $R \& D$ expenditures since both of these public policy instruments are currently available to Slovenian companies.

Accordingly, this paper makes several contributions. First, it examines the impact of both public policy instruments on firms' R\&D spending. There is namely no unequivocal answer to the question of what is more effective because different results suggest different public policies and different solutions. Second, it presents an empirical study for Slovenia, a small open economy. Smaller countries are often characterised by different properties than larger ones, especially in their financial systems. Finally, it examines the relationship between public support for R\&D investment and firms' R\&D expenditures on a sample of chiefly smaller and nonlisted companies given that smaller and non-listed companies often have different needs in funding their business activities than larger and listed ones. The mentioned contributions make this study unique in the economic literature.

\section{Theoretical Considerations and Literature Review}

\subsection{Theoretical Foundations}

According to the theory, the main rationale for public support for R\&D investment is often represented by the concept of market failure, typically considered to be the core reason for market inefficiency. In this context, market failure refers to the market underinvesting in private $\mathrm{R} \& \mathrm{D}$, which implies that the level of private $\mathrm{R} \& \mathrm{D}$ investment is below the socially desirable level (Arrow, 1962). The reasons for such 
underinvestment stem from the existence of conditions that prevent companies from fully realising the benefits of their R\&D investment (Link and Scott, 2013). The biggest market failures relevant to $R \& D$ activity relate to positive externalities, information asymmetry, and uncertainty and risk.

The first important market failure concerns positive externalities. Namely, R\&D investments are often subject to considerable spillovers, implying it is relatively easy for other companies to take advantage of R\&D investments they themselves do not make (Haskel and Westlake, 2018). Knowledge or ideas created by R\&D activity are essentially a public good characterised by non-rivalry and non-excludability. On one hand, non-rivalry means the results of an $R \& D$ activity can be used by several entities at the same time at zero cost. On the other hand, non-excludability relates to the fact that it is almost impossible to exclude entities from using new knowledge or ideas created by the R\&D activity once they have been supplied to certain other entities (Oosterbaan et al., 2000).

Due to the existence of different legal intellectual protection mechanisms such as patents and copyrights, R\&D investment may be considered to be partially nonexcludable, whereby is it still very difficult for companies to fully protect all of the knowledge gained through R\&D activity and to prevent other companies from using this knowledge. Summing up, the benefits of non-rival and (partially) nonexcludable R\&D investment are likely to spill over beyond the companies that make them. Therefore, where companies are unable to benefit fully from their own R\&D investment and prevent their competitors from taking advantage of from spillovers, this will cause much lower private R\&D investment than is socially desirable.

Another market failure refers to information asymmetry. In this context, one encounters two main obstacles to R\&D financing which largely result from information asymmetries between borrowers/companies and lenders/financiers. These refer to adverse selection and moral hazard. The issue of adverse selection relates to hidden information. Namely, financiers are often unable to objectively establish the successfulness of an R\&D project since the companies performing R\&D activities possess better information regarding a certain $R \& D$ project. Consequently, this implies that, on average, $R \& D$ projects offered for external finance are more likely to be less successful. In addition, the issue of moral hazard refers to hidden action.

That is to say, companies might ex-post take on a higher level of risk than originally agreed with the financier and generate larger profits if a certain R\&D project is successful. Yet, in this case, the financiers would bear the additional risk of bankruptcy (Bakker, 2013). The aforementioned issues of information asymmetry may therefore narrow the financial opportunities available for companies to perform R\&D activities. 
The third market failure is associated with uncertainty and risk, which together represent an important issue for R\&D activity (Czarnitzki, 2006). In this perspective, four different types of uncertainty can be identified: technical, strategic, market and profit uncertainty. Technical uncertainty relates to the situation when companies are unsure whether R\&D expenditures will lead to a useful and working innovation. Moreover, even if the opposite occurs, there is the question of whether this innovation is what was originally expected. Strategic uncertainty refers to the uncertainty that depends on the actions of one's competitors. Namely, companies often face the question of whether the competitors are doing similar R\&D activities and, if so, whether the competitors are able to launch their product first on the market.

Market uncertainty is related to uncertainty about whether the market of the innovation remains the same as it was expected to be when the particular R\&D activity commenced. Finally, profit uncertainty refers to whether companies' business models are able to capture the benefits of R\&D activity (Bakker, 2013). All of the above-mentioned uncertainty and risk perceptions may result in underinvesting in R\&D.

Briefly, the existence of the above market failures cause market mechanisms to deteriorate as they fail to provide a socially desirable level of private R\&D investment in the business sector. This implies that public support for R\&D investment should play an important role in addressing certain market failures since their appropriate introduction can help cut the cost of R\&D investment. From a theoretical perspective, the main channel via which public support for R\&D investment can affect companies' investment in $\mathrm{R} \& \mathrm{D}$ activities is the reduction of the user cost of the R\&D investment, meaning that otherwise too expensive R\&D activities are also performed (Bloom et al., 2002; Hud and Hussinger, 2015). This holds for both R\&D subsidies and R\&D tax incentives.

On one hand, R\&D subsidies lower the demand for funding through external sources, implying a lower cost of debt. This is then reflected in the lower overall cost of financing R\&D activity (Takalo et al., 2013; Rupeika-Apoga and Saksonova, 2018). On the other hand, $R \& D$ tax incentives reduce the cost of $R \& D$ activity by lowering the tax liability (Baldacchino et al., 2019; Dosmanbetova et al., 2018; Gashi et al., 2018; Liu, 2013; Vokshi, 2018; Yulianto and Chariri, 2019). Yet, the benefits of $\mathrm{R} \& \mathrm{D}$ tax incentives depend on the existence of a positive tax base, which is a necessary precondition to claim them (Bernstein, 1986; Solovjova et al., 2018).

\subsection{Literature Review on the Joint Effect of R\&D Subsidies and Tax Incentives}

Despite the extensive economic literature that deals with only $R \& D$ subsidies or R\&D tax incentives at one time, empirical studies that simultaneously consider both instruments of public support for R\&D investment are scarce. Nonetheless, some studies focus on how companies use R\&D subsidies and R\&D tax incentives at the 
same time by assessing the impact on firms' R\&D expenditures (Carboni, 2011), their innovative or corporate performance (Bérubé and Mohnen, 2009; Radas et al., 2015) or by examining the determinants of the choice of a certain instrument of public support (Busom et al., 2014).

The empirical results given by Carboni (2011) for Italy suggest that public support for R\&D investment positively impacts companies' R\&D investment, meaning that companies which use instruments of public support devote more of their own resources than in absence of public support. The results also reveal that R\&D tax incentives are more effective than R\&D subsidies. Finally, there is also some evidence in this study that public support has positive effects for credit financing for $\mathrm{R} \& \mathrm{D}$.

Further, Bérubé and Mohnen (2009) examine the effectiveness of R\&D subsidies and R\&D tax incentives in Canada by comparing the innovation performance of companies that benefited from R\&D tax incentives only with their counterparts which benefited from both, namely R\&D tax incentives and R\&D subsidies. They have claimed that the dual use of both instruments of public support is more effective than the use of $R \& D$ tax incentives alone. One can thus say that companies which benefited from these two instruments of public support introduced more products, were responsible for more 'world-first' product innovations and enjoyed greater success in commercialising their innovations than their rivals that benefited solely from R\&D tax incentives.

Radas et al. (2015) investigate the effects of R\&D subsidies and R\&D tax incentives on SMEs in Croatia. They find that, either used alone or with R\&D tax incentives, R\&D subsidies add to the R\&D orientation, innovation output and absorptive capacity of SMEs. The effects of instruments of public support become especially obvious when comparing these companies with those that did not benefit from either instrument. When comparing just the beneficiaries of R\&D subsidies with the companies that used both instruments of public support ( $\&$ D subsidies and $R \& D$ tax incentives), not much difference is found. These results suggest that, when it comes to SMEs, R\&D subsidies take precedence over $R \& D$ tax incentives since in this case the latter do not contribute to greater $R \& D$ spending.

In the context of Spain, Busom et al. (2014) investigate the use of R\&D subsidies and $R \& D$ tax incentives in addressing financing constraints and appropriability difficulties, which represent two sources of market failure. They also examine whether the two instruments of public support for R\&D investment act as substitutes. Their findings reveal that SMEs faced with financing constraints (whether internal or external) are more likely to use R\&D subsidies than R\&D tax incentives. In the case of SMEs, they also establish that SMEs utilising legal intellectual protection mechanisms are more likely to use $R \& D$ tax incentives even if financing constraints increase. The findings for large companies show that large companies facing external financing constraints prefer $\mathrm{R} \& \mathrm{D}$ subsidies over $\mathrm{R} \& \mathrm{D}$ tax incentives. 
With respect to large companies, they do not establish a relationship between the use of intellectual protection mechanisms and the use of only one instrument of public support. The authors conclude by stating a common finding pertaining to both SMEs and large companies. They claim that both prefer R\&D tax incentives (either alone or combined with $R \& D$ subsidies) where they have past $R \& D$ experience. They additionally establish that young companies operating in knowledge-intensive industries prefer $R \& D$ subsidies over $R \& D$ tax incentives. The authors conclude that R\&D subsidies and $R \& D$ tax incentives possess distinct abilities, especially in addressing the causes of market failures. From the policy point of view, these two instruments of public support may therefore be regarded as complementing each other.

The review of the literature on the joint effect of $R \& D$ subsidies and $R \& D$ tax incentives reveals that generally speaking to a greater or a smaller extent both instruments enhance firms' R\&D expenditures, improve their innovation performance and correct market failures. Despite the beneficial effect of R\&D subsidies and R\&D tax incentives, the way these two instruments of public support influence companies may be different, especially due to the existence of some differential features related to the eligibility, magnitude and certainty as well as timing of public support (Busom et al., 2014).

As regards eligibility for public support, all $R \& D$ projects are qualified for $R \& D$ tax credits if they meet all of the conditions for classifying them as an R\&D activity, although this does not apply to R\&D subsidies where only R\&D projects revealing a high level of novelty, risk or spillover capacity may qualify for a subsidy.

In terms of the magnitude of public support, R\&D subsidies provide companies with greater certainty regarding the extent of $\mathrm{R} \& \mathrm{D}$ cost reduction. For example, beneficiaries of $R \& D$ subsidies know the exact amount of the R\&D subsidies in advance before starting the $R \& D$ project, whereby the benefits of $R \& D$ tax incentives mostly depend on a company's tax position at the end of the fiscal year. Namely, the amount of tax liability at the end of the fiscal year might be smaller than the benefits of the potential R\&D tax incentives. This often occurs in the case of SMEs and young companies. In this sense, in the case of companies faced with financing constraints (whether internal or external), R\&D subsidies are more beneficial than R\&D tax incentives since financially-constrained companies cannot generate sufficient R\&D expenditures to qualify for R\&D tax incentives.

With respect to the timing of public support, $R \& D$ subsidies are obtained ex ante before the R\&D project starts, while $R \& D$ tax incentives are obtained ex post at the end of the fiscal year. Thus, companies can only benefit from R\&D tax incentives if they have enough of their own internal or external financial resources to fund the R\&D project in advance. Since SMEs and young companies often encounter financing constraints, they are less likely to benefit from $R \& D$ tax incentives. Further, R\&D subsidies may also serve as an indicator of the quality of an R\&D 
project, allowing companies to signal their success to potential investors. This means that, due to the certification effect, the receipt of R\&D subsidies may lead to easier access to external finance (Meuleman and De Maeseneire, 2012; Wu, 2017). Yet this is not the case for $\mathrm{R} \& \mathrm{D}$ tax incentives. A summary and comparison of the characteristics of $R \& D$ subsidies and $R \& D$ tax incentives is presented in Table 1.

Table 1. Comparison of $R \& D$ subsidies and $R \& D$ tax incentives by individual characteristics

\begin{tabular}{|c|l|l|}
\hline Characteristics & \multicolumn{1}{|c|}{ R\&D subsidies } & \multicolumn{1}{|c|}{ R\&D tax incentives } \\
\hline Eligibility & $\begin{array}{l}\text { Only R\&D projects accomplishing } \\
\text { funding agency requirements. }\end{array}$ & $\begin{array}{l}\text { All R\&D projects funded by } \\
\text { companies own internal or } \\
\text { external finances. }\end{array}$ \\
\hline $\begin{array}{c}\text { Magnitude and } \\
\text { certainty }\end{array}$ & $\begin{array}{l}\text { Depends on the amount of R\&D } \\
\text { subsidies, which companies know } \\
\text { in advance (greater certainty). }\end{array}$ & $\begin{array}{l}\text { Depends on a company's tax } \\
\text { position at the end of the fiscal } \\
\text { year (less certainty). }\end{array}$ \\
\hline Timing & $\begin{array}{l}\text { Obtained } \text { ex ante before the R\&D } \\
\text { project starts. }\end{array}$ & $\begin{array}{l}\text { Obtained } \text { ex post at the end of the } \\
\text { fiscal year. }\end{array}$ \\
\hline
\end{tabular}

Source: Busom et al., 2014.

The extensive literature review shoes that both forms of public support for R\&D investment have generally positive effects. However, the vast majority of empirical studies mostly focus on a single public policy instrument, i.e. R\&D subsidies or R\&D tax incentives. Since two different instruments of public support for R\&D investment are available in Slovenia, two different research hypotheses are developed. The first one concerns R\&D subsidies, which are considered as direct public support for $R \& D$ investment. It is generally expected that $R \& D$ subsidies should enhance firms' R\&D expenditures. Yet, the specific nature of R\&D subsidies in terms of eligibility, magnitude and certainty as well as timing may hold important implications for their effectiveness. Therefore, the following research hypothesis is proposed:

Hypothesis 1: Direct public support for $R \& D$ investment in the form of $R \& D$ subsidies stimulates $R \& D$ expenditures, where its specific nature makes it a less effective instrument than indirect public support in the form of $R \& D$ tax incentives.

Another important instrument of public support for $R \& D$ investment is $R \& D$ tax incentives, which are regarded as indirect support for $R \& D$ investment. Like with R\&D subsidies, R\&D tax incentives are often expected to bring beneficial effects for firms' R\&D spending. However, given the broader or more general nature of R\&D tax incentives it can also be anticipated that they are an effective instrument for a wider population of companies. Therefore, the following research hypothesis is posited:

Hypothesis 2: Indirect public support for $R \& D$ investment in the form of $R \& D$ tax incentives stimulates $R \& D$ expenditures with its more general nature making it an effective instrument for a wider population of companies. 


\section{Data and Research Methods}

\subsection{Sample Selection}

A comprehensive empirical analysis is performed on a unique dataset of Slovenian companies. The data come from three main different sources is obtained from the Statistical Office of the Republic of Slovenia, which provides R\&D survey data for Slovenian companies (SORS, 2018). It provides also the data from the Agency of the Republic of Slovenia for Public Legal Records and Related Services (AJPES) covering balance-sheet and income-statement data and the data from the Financial Administration of the Republic of Slovenia (FURS) covering data taken from corporation tax forms. The nature of the empirical analysis requires a period in which both instruments of public support for R\&D investment were available to Slovenian companies. Moreover, the research period that is needed must encompass stable operating conditions. Ever since $R \& D$ tax incentives were introduced in Slovenia in 2005, they have been subject to considerable changes in terms of their rates. The latest major change in the R\&D tax allowance rate was in 2012 when the rate rose significantly to $100 \%$. After that, no significant changes have affected the R\&D tax allowance rate in Slovenia. Nevertheless, changes like this could produce a situation in which companies opportunistically time their patterns of R\&D spending so as to obtain additional benefits from R\&D tax incentives (Chen and Gupta, 2018). Therefore, the research period for the empirical analysis is restricted to the latest available data for the five-year period 2012-2016.

The final sample consists of Slovenian non-financial private companies operating in either the manufacturing (NACE 10-33) or service sectors (NACE 35-99) and taking the legal organisational form of a private or public limited company; namely, such companies are a good reflection of Slovenia's small open economy. Moreover, company-year observations with incomplete data, negative equity or less than one employee are excluded from the empirical analysis. Finally, in order to mitigate the small deflator problem, company-year observations with less than EUR 100,000 of total assets and net sales are excluded from the analysis. The final unbalanced panel dataset of Slovenian companies consists of 3,113 company-year observations. The distribution of the final sample of Slovenian companies by years is shown in Table 2.

Table 2. Sample distribution of Slovenian companies by years

\begin{tabular}{|c|c|c|}
\hline Year & No. & Share (in \%) \\
\hline 2012 & 541 & 17.38 \\
\hline 2013 & 615 & 19.76 \\
\hline 2014 & 675 & 21.68 \\
\hline 2015 & 667 & 21.43 \\
\hline 2016 & 615 & 19.76 \\
\hline Total & $\mathbf{3 , 1 1 3}$ & $\mathbf{1 0 0}$ \\
\hline
\end{tabular}

Source: SORS, 2018; own calculations. 


\subsection{Variables}

\subsubsection{Dependent Variable}

This empirical study looks specifically at the impact of different public support for $R \& D$ investment on firms' R\&D expenditures. Since the principal interest of this study is R\&D expenditures funded by companies themselves, the dependent variable measures firms' R\&D expenditures without R\&D subsidies, data for which are provided by different Slovenian and EU institutions. Accordingly, net R\&D intensity (NRDI) is defined as firms' $R \& D$ expenditures (excluding R\&D subsidies) divided by total assets. This measure represents a comparable basis for companies of different sizes and is widely used in existing empirical studies (Curtis et al., 2016; Ryan Jr, 2002).

\subsubsection{Independent Variables}

This empirical study is interested in two main independent variables which try to capture the scope of a certain instrument of public support for $R \& D$ investment. These are R\&D subsidy intensity (SUB) and R\&D tax incentive intensity (TAX). They are defined as the amount of $R \& D$ subsidies received or $R \& D$ tax incentives claimed divided by the amount of net sales. Such measures are also used in other empirical studies (Jin et al., 2018). In order to obtain additional and comprehensive insights regarding how public support for R\&D investment impacts firms' $R \& D$ expenditures, the following interaction effects are considered in the analysis. The first interaction term between R\&D subsidy intensity and R\&D tax incentive intensity (SUBxTAX) tries to capture the simultaneous use of both public policy instruments. The second interaction term between R\&D subsidy intensity and net sales growth (SUBxNSG) is considered as part of examining how R\&D subsidies influence firms' R\&D spending relative to company growth. Similarly, the third interaction term between $\mathrm{R} \& \mathrm{D}$ tax incentive intensity and net sales growth (TAXxNSG) is considered for the purposes of establishing how R\&D tax incentives affect firms' R\&D expenditures in relation to company growth. According to the proposed research hypotheses, it is expected that both forms of public support for $R \& D$ investment ( $\& \& D$ subsidies and $R \& D$ tax incentives) as well as their interaction terms positively impact firms' R\&D expenditures.

\subsubsection{Control Variables}

Existing empirical studies suggest several factors may impact firms' $R \& D$ expenditures. The first control variable is financial leverage (LEV), measured as total (short-term and long-term) liabilities divided by total assets. According to previous empirical studies, it is expected that financial leverage has a negative impact on firms' R\&D expenditures (Min and Smyth, 2016). Namely, financial leverage may be considered a channel through which companies can obtain additional financial resources which they invest in R\&D activities. When a company approaches to its debt limit, obtaining debt financing becomes increasingly difficult and may limit the company's R\&D activities. Yet, some companies, especially smaller ones, may encounter difficulties accessing debt markets since $\mathrm{R} \& \mathrm{D}$ 
investment is risky and uncertain, making it difficult to use it as collateral (VincenteLorente, 2001). The second control variable is company net sales growth (NSG), measured as simple 1-year growth of net sales, which is expected to positively impact firms' R\&D expenditures (Coad and Rao, 2010). It is established in the literature that growing companies typically experience increasing profitability, while loss-making companies eventually exit the market (Jovanovic, 1982). Thus, growing companies, which usually also exhibit profits, can then obtain extra funding available for different investment activities like R\&D activity.

The third control variable is company size (SIZE), measured as the natural logarithm of employees. Empirical studies show that large companies tend to devote greater funding to R\&D investment (Meisel and Lin, 1983). Namely, larger companies often have better access to capital markets, allowing them to obtain more funds for R\&D activity (Nunes et al., 2009; Titman and Wessles, 1988). Moreover, besides the size of a company, this control variable captures human capital. It is generally believed in the literature that human capital is an important determinant of R\&D spending (Pingfang and Weimin, 2003). It is therefore expected that company size has a positive impact on firms' R\&D spending (Jin et al., 2018). In addition, year dummy variables (YEAR) are included in the empirical analysis to control for time effects. Based on 2012, there are four dummy variables which take the value of 1 if a company-year observation is from a year studied (from 2013 to 2016), and 0 otherwise. A summary of all variables employed in the empirical analysis is presented in Table 3.

\subsection{Research Methods}

This empirical study involves a comprehensive empirical analysis of the impact of different forms of public support for R\&D investment on firms' R\&D expenditures. The first step entails estimating the impact of different public policy instruments, namely $R \& D$ subsidies and $R \& D$ tax incentives, as well as their interaction term on firms' R\&D expenditures. Net R\&D intensity (NRDI) is accordingly regressed against the main independent variables, i.e. $R \& D$ subsidy intensity (SUB), R\&D tax incentive intensity (TAX), and the interaction term between R\&D subsidy intensity and R\&D tax incentive intensity (SUBxTAX) as measures of public support for R\&D investment (SUP). They are estimated in separate models as well as simultaneously. In addition, some control variables are further included in the multiple regression models, i.e. financial leverage (LEV), net sales growth (NSG) and company size (SIZE). In order to control for year effects, time dummy variables (YEAR) are also considered. The multiple regression model is presented in Equation (1) where the main independent variables of interest (SUP) are presented as a vector.

$$
N R D I_{i, t}=a_{0}+\beta_{1} S U P_{i, t}+\beta_{2} L E V_{i, t}+\beta_{3} N S G_{i, t}+\beta_{4} S I Z E_{i, t}+\sum Y E A R_{i, t}+\varepsilon_{i, t, t}
$$


Table 3. Summary of the variables used in the empirical analysis

\begin{tabular}{|c|c|c|c|}
\hline Abbreviation & Variable & Definition & Source \\
\hline \multicolumn{4}{|c|}{ Dependent variable } \\
\hline NRDI & Net R\&D intensity & $\begin{array}{l}\text { The ratio between firms' } \\
\text { R\&D expenditures and total } \\
\text { assets. }\end{array}$ & SORS \\
\hline \multicolumn{4}{|c|}{ Independent variables } \\
\hline SUB & $\begin{array}{l}\text { R\&D subsidy } \\
\text { intensity }\end{array}$ & $\begin{array}{l}\text { The ratio between received } \\
\text { R\&D subsidies and total } \\
\text { assets. }\end{array}$ & SORS \\
\hline TAX & $\begin{array}{l}\mathrm{R} \& \mathrm{D} \text { tax incentive } \\
\text { intensity }\end{array}$ & $\begin{array}{l}\text { The ratio between claimed } \\
\text { R\&D tax incentives and total } \\
\text { assets. }\end{array}$ & FURS \\
\hline SUBxTAX & $\begin{array}{l}\text { Interaction between } \\
\text { R\&D subsidy } \\
\text { intensity and R\&D } \\
\text { tax incentive intensity }\end{array}$ & $\begin{array}{l}\text { The interaction between } R \& D \\
\text { subsidy intensity and } R \& D \\
\text { tax incentive intensity. }\end{array}$ & SORS/FURS \\
\hline SUBxNSG & $\begin{array}{l}\text { Interaction term } \\
\text { between R\&D } \\
\text { subsidy intensity and } \\
\text { net sales growth }\end{array}$ & $\begin{array}{l}\text { The interaction between } R \& D \\
\text { subsidy intensity and } \\
\text { company net sales growth. }\end{array}$ & SORS/AJPES \\
\hline TAXxNSG & $\begin{array}{l}\text { Interaction term } \\
\text { between R\&D tax } \\
\text { incentive intensity } \\
\text { and net sales growth }\end{array}$ & $\begin{array}{l}\text { The interaction between R\&D } \\
\text { tax incentive intensity and } \\
\text { company net sales growth. }\end{array}$ & FURS/AJPES \\
\hline \multicolumn{4}{|c|}{ Control variables } \\
\hline LEV & Financial leverage & $\begin{array}{l}\text { The ratio between total } \\
\text { liabilities and total assets. }\end{array}$ & AJPES \\
\hline NSG & Net sales growth & $\begin{array}{l}\text { Simple 1-year growth of net } \\
\text { sales. }\end{array}$ & AJPES \\
\hline SIZE & Company size & $\begin{array}{l}\text { The natural logarithm of } \\
\text { employees. }\end{array}$ & AJPES \\
\hline YEAR & Year dummy variable & $\begin{array}{l}\text { Dummy variable that takes } 1 \\
\text { for a year studied, } 0 \\
\text { otherwise. }\end{array}$ & AJPES \\
\hline
\end{tabular}

Note: SORS - Statistical Office of the Republic of Slovenia; FURS - Financial Administration of the Republic of Slovenia; AJPES - Agency of the Republic of Slovenia for Public Legal Records and Related Services.

Source: Own presentation.

In order to obtain further insights, the second step is concerned with the impact of different public policy instruments, namely, R\&D subsidies and R\&D tax incentives, by considering their interaction with net sales growth. Accordingly, net R\&D intensity (NRDI) is regressed against the main independent variables, i.e. R\&D subsidy intensity (SUB), R\&D tax incentive intensity (TAX), as well as their interaction terms with net sales growth (SUBxNSG and TAXxNSG) denoted by (INT). They are estimated both in separate models and simultaneously. Like in the first step, financial leverage (LEV), net sales growth (NSG) and company size 
(SIZE) are considered as control variables. In order to control for year effects, time dummy variables (YEAR) are also taken into consideration. The multiple regression model is presented in Equation (2) where the main independent variables of interest (INT) are presented as a vector.

$$
N R D I_{i, t}=\alpha_{0}+\beta_{1} S U B_{i, t}+\beta_{2} T_{A X} X_{i, t}+\beta_{3} I N T_{i, t}+\beta_{4} L E V_{i, t}+\beta_{5} N S G_{i, t}+\beta_{6} S I Z E_{i, t}+\sum Y E A R_{i, t}+\varepsilon_{i, t}
$$

\section{Empirical Results}

\subsection{Descriptive Statistics}

Descriptive statistics of variables (except year and interaction effects) for the period 2012-2016 are presented in Table 4. Since companies represent a very heterogeneous group of units, there may be some outliers in the data. In order to eliminate the effect of possibly spurious outliers, all of the continuous variables are winsorised at the $1 \%$ and $99 \%$ levels by each year. Further, the Winsorisation procedure is often also considered as robust statistics (Reifman and Keyton, 2010).

Table 4. Descriptive statistics

\begin{tabular}{|c|c|c|}
\hline Variable & Mean & SD \\
\hline NRDI & 0.111 & 0.216 \\
\hline SUB & 0.021 & 0.070 \\
\hline TAX & 0.031 & 0.055 \\
\hline LEV & 0.427 & 0.223 \\
\hline NSG & 0.112 & 0.439 \\
\hline SIZE & 3.624 & 1.605 \\
\hline
\end{tabular}

Note: Data for Slovenian companies are strictly confidential so the minimum and maximum values for an individual variable are not shown.

Source: SORS, 2018; own calculations.

The descriptive statistics presented above reveal that Slovenian companies devote funds for R\&D activity in a proportion exceeding $11 \%$ of their total assets. Moreover, the mean values of R\&D subsidy intensity (SUB) and R\&D tax incentive intensity (TAX) suggest the latter are more popular among Slovenian companies than $R \& D$ subsidies. The mean value of financial leverage (LEV) indicates it is at a relatively high level compared to net R\&D intensity (NRDI). Finally, the descriptive statistics reveal that on average Slovenian companies grow at a rate of $11.20 \%$.

Table 5 shows Pearson's correlations between variables (except year and interaction effects). The simple correlation shows a positive and significant correlation between different forms of public support for R\&D investment and firms' R\&D expenditures. The Pearson correlation matrix also reveals that financial leverage (LEV) and company size (SIZE) are negatively correlated with firms' R\&D expenditures. 
Finally, the correlation between net sales growth (NSG) and firms' R\&D expenditures seems to be positive. These results are largely (except for company size) in line with the expectations. Nevertheless, the simple correlation between the explanatory variables does not indicate any strong linear relationship, suggesting there is no issue of multicollinearity in the data of these Slovenian companies.

Table 5. Pearson correlation matrix of variables for the Slovenian companies

\begin{tabular}{|c|c|c|c|c|c|c|}
\hline Variable & NRDI & SUB & TAX & LEV & NSG & SIZE \\
\hline NRDI & 1 & & & & & \\
\hline SUB & $0.293^{* * *}$ & 1 & & & & \\
\hline TAX & $0.265^{* * *}$ & $0.088^{* * *}$ & 1 & & & \\
\hline LEV & $-0.783^{* * *}$ & 0.001 & $-0.232^{* * *}$ & 1 & & \\
\hline NSG & $0.137^{* * *}$ & $0.152^{* * *}$ & $0.189^{* * *}$ & $0.048^{* *}$ & 1 & \\
\hline SIZE & $-0.316^{* * *}$ & $-0.206^{* * *}$ & $-0.277^{* * *}$ & $0.054^{* *}$ & $-0.144^{* * *}$ & 1 \\
\hline
\end{tabular}

Note: Levels of significance: $* p<0.05 ; * * p<0.01 ; * * * p<0.001$.

Source: SORS, 2018; own calculations.

\subsection{Multiple Regression Analysis}

This paper looks at the impact of public R\&D policy on business $R \& D$ expenditures. In order to obtain detailed insights, the empirical analysis is performed in two separate, yet interrelated steps. The first step estimates the impact of different public policy instruments on firms' R\&D expenditures, while the second step further investigates their impact on firms' R\&D expenditures according to company growth. Multiple regression models may be estimated by using three main different alternative econometric specifications: the pooled regression model, the random effects model and the fixed effects model. Based on a three-step procedure of different model specification tests (LM test, F test and Hausman test), it is statistically determined that the fixed effects model is the most preferred among all of the multiple regression models. Moreover, the heteroscedasticity-robust (White) standard errors are employed in the multiple regression models in order to alleviate the problem of heteroscedasticity.

The empirical results for the relationship between public support for $R \& D$ investment and firms' $R \& D$ expenditures are presented in Table 6. As regards the impact of two different forms of public support, the empirical results are as follows. The regression coefficients of R\&D subsidy intensity (SUB) reveal it has a negative impact on net R\&D intensity (NRDI), while the regression coefficient of R\&D tax incentive intensity (TAX) shows it has a positive impact on net R\&D intensity (NRDI). These results are evident in Model 1(a) and Model 1(b), which estimate only one individual public policy instrument, i.e. $R \& D$ subsidies or $R \& D$ tax incentives. Since these results might be biased due to the inclusion of only a single instrument of public support in the estimation, Model 1(c) extends the previous models by considering the simultaneous impact of the two public policy instruments. In this case, the empirical results remain similar. The regression coefficient of R\&D 
subsidy intensity (SUB) suggests that a $1 \%$ increase in R\&D subsidy intensity (SUB) leads to a $0.347 \%$ decrease in net R\&D intensity (NRDI). On the contrary, the regression coefficient of $R \& D$ tax incentive intensity (TAX) suggests that a $1 \%$ increase in $R \& D$ tax incentive intensity (TAX) leads to a $0.245 \%$ increase in net R\&D intensity (NRDI). All of these regression coefficients are significant at the $0.1 \%$ level and reveal the impact on firms' $R \& D$ expenditures is negative for $R \& D$ subsidies and positive for R\&D tax incentives. Moreover, the results for the control variables are in line with the initial expectations.

Since Slovenian companies are allowed to benefit from both forms of public support for R\&D investment, it is necessary to include the interaction between R\&D subsidy intensity and R\&D tax incentive intensity (SUBxTAX). The empirical results of Model 1 (d) reveal the following. The impact on net R\&D intensity (NRDI) is significantly negative for R\&D subsidy intensity (SUB) and non-significantly positive for R\&D tax incentive intensity (TAX). However, the main interest in this multiple regression model is the interaction between $R \& D$ subsidy intensity and R\&D tax incentive intensity (SUBxTAX), which is positive and highly significant. This suggests that the dual use of both $R \& D$ subsidies and R\&D tax incentives stimulates firms' R\&D expenditures. Moreover, the results for the control variables are in line with the initial expectations.

Table 6. Multiple regression results for the relationship between public support for $R \& D$ investment and firms' $R \& D$ expenditures

\begin{tabular}{|c|c|c|c|c|c|}
\hline Variable & $\begin{array}{l}\text { Predicted } \\
\text { Sign }\end{array}$ & $\begin{array}{l}\text { Model } 1 \\
\text { (a) NRDI }\end{array}$ & $\begin{array}{l}\text { Model } 1 \\
\text { (b) NRDI }\end{array}$ & $\begin{array}{l}\text { Model 1 } \\
\text { (c) NRDI }\end{array}$ & $\begin{array}{l}\text { Model } 1 \\
\text { (d) NRDI }\end{array}$ \\
\hline SUB & + & $\begin{array}{c}-0.342^{* * *} \\
(0.045)\end{array}$ & & $\begin{array}{c}-0.347^{\text {*** }} \\
(0.045)\end{array}$ & $\begin{array}{c}-0.477^{* * *} \\
(0.051)\end{array}$ \\
\hline TAX & + & & $\begin{array}{c}0.233^{* * * *} \\
(0.064)\end{array}$ & $\begin{array}{l}0.245^{\text {**** }} \\
(0.063)\end{array}$ & $\begin{array}{c}0.091 \\
(0.069)\end{array}$ \\
\hline SUBxTAX & + & & & & $\begin{array}{c}2.174^{* * * *} \\
(0.388)\end{array}$ \\
\hline LEV & - & $\begin{array}{c}-0.060^{* *} \\
(0.023)\end{array}$ & $\begin{array}{c}-0.061^{* * *} \\
(0.023)\end{array}$ & $\begin{array}{l}-0.050^{*} \\
(0.023)\end{array}$ & $\begin{array}{l}-0.054^{*} \\
(0.023)\end{array}$ \\
\hline NSG & + & $\begin{array}{c}0.027^{* * * *} \\
(0.005)\end{array}$ & $\begin{array}{l}0.019^{* * * *} \\
(0.005)\end{array}$ & $\begin{array}{l}0.024^{* * * *} \\
(0.005)\end{array}$ & $\begin{array}{c}0.025^{* * * *} \\
(0.005)\end{array}$ \\
\hline SIZE & + & $\begin{array}{l}0.023^{* * *} \\
(0.010)\end{array}$ & $\begin{array}{c}0.015 \\
(0.010)\end{array}$ & $\begin{array}{c}0.024^{*} \\
(0.010)\end{array}$ & $\begin{array}{c}0.025^{*} \\
(0.010)\end{array}$ \\
\hline Constant & $?$ & $\begin{array}{l}0.081^{* *} \\
(0.037)\end{array}$ & $\begin{array}{c}0.093^{*} \\
(0.038)\end{array}$ & $\begin{array}{c}0.066 \\
(0.037)\end{array}$ & $\begin{array}{c}0.069 \\
(0.037)\end{array}$ \\
\hline Year & $?$ & Yes & Yes & Yes & Yes \\
\hline \multicolumn{2}{|c|}{$\mathrm{R}^{2}$} & 0.1038 & 0.0032 & 0.0716 & 0.0830 \\
\hline \multicolumn{2}{|c|}{ Observations } & 3,113 & 3,113 & 3,113 & 3,113 \\
\hline \multicolumn{2}{|c|}{ LM test } & $1,872.16^{* * *}$ & $2,223.95^{\text {**** }}$ & $1,830.23^{* * *}$ & $1,795.46^{\text {**** }}$ \\
\hline \multicolumn{2}{|c|}{ F test } & $156.00^{* * *}$ & $27.66^{* * *}$ & $168.21^{\text {**** }}$ & $192.29^{* * *}$ \\
\hline \multicolumn{2}{|c|}{ Hausman test } & $168.69^{* * *}$ & $44.90^{* * * *}$ & $185.98^{* * *}$ & $207.92^{* * * *}$ \\
\hline
\end{tabular}

Note: 1) Levels of significance: $* p<0.05 ; * * p<0.01 ; * * * p<0.001 .2)$ Heteroscedasticityrobust standard errors are in parentheses.

Source: SORS, 2018; own calculations. 
The empirical results for the relationship between public support for $R \& D$ investment and firms' R\&D expenditures according to their growth are presented in Table 7. The main variables of interest in this step of the empirical analysis are the interactions between R\&D subsidy intensity, R\&D tax incentive intensity, and net sales growth (SUBxNSG and TAXxNSG). These interactions are estimated separately (see Model 2(a) and Model 2(b)) and together (see Model 2(c)). Regardless of the empirical results for other relevant variables, which remain similar to those presented in the first step of the analysis, the results for the interaction terms give the following insights. The regression coefficients of both interaction terms are positive and significant, suggesting that both forms of public support for $R \& D$ investment positively impact firms' $R \& D$ spending for growing companies. The empirical results remain similar regardless of the model estimated. Moreover, the results for the control variables are in line with the initial expectations.

Table 7. Multiple regression results for the relationship between public support for $R \& D$ investment and firms' $R \& D$ expenditures according to their growth

\begin{tabular}{|c|c|c|c|c|}
\hline Variable & $\begin{array}{l}\text { Predicted } \\
\text { Sign }\end{array}$ & $\begin{array}{c}\text { Model } 2 \\
\text { (a) } \\
\text { NRDI }\end{array}$ & $\begin{array}{c}\text { Model } 2 \\
\text { (b) } \\
\text { NRDI }\end{array}$ & $\begin{array}{c}\text { Model } 2 \\
\text { (c) } \\
\text { NRDI }\end{array}$ \\
\hline SUB & + & $\begin{array}{c}-0.395^{* * *} \\
(0.049)\end{array}$ & $\begin{array}{c}-0.339^{* * *} \\
(0.045)\end{array}$ & $\begin{array}{c}-0.393^{* * *} \\
(0.049)\end{array}$ \\
\hline TAX & + & $\begin{array}{c}0.262^{* * *} \\
(0.064)\end{array}$ & $\begin{array}{c}0.126 \\
(0.068)\end{array}$ & $\begin{array}{l}0.141^{*} \\
(0.068)\end{array}$ \\
\hline SUBxNSG & + & $\begin{array}{l}0.087^{*} \\
(0.035)\end{array}$ & & $\begin{array}{l}0.097^{* * *} \\
(0.035)\end{array}$ \\
\hline TAXxNSG & + & & $\begin{array}{c}0.273^{* * *} \\
(0.059)\end{array}$ & $\begin{array}{c}0.282^{* * *} \\
(0.059)\end{array}$ \\
\hline LEV & - & $\begin{array}{l}-0.051^{*} \\
(0.023)\end{array}$ & $\begin{array}{l}-0.049^{*} \\
(0.023)\end{array}$ & $\begin{array}{l}-0.051^{*} \\
(0.023)\end{array}$ \\
\hline NSG & + & $\begin{array}{l}0.016^{* *} \\
(0.006)\end{array}$ & $\begin{array}{c}0.008 \\
(0.006)\end{array}$ & $\begin{array}{l}-0.001 \\
(0.007)\end{array}$ \\
\hline SIZE & + & $\begin{array}{l}0.024^{*} \\
(0.010)\end{array}$ & $\begin{array}{l}0.027^{* * *} \\
(0.010)\end{array}$ & $\begin{array}{l}0.028^{* *} \\
(0.010)\end{array}$ \\
\hline Constant & $?$ & $\begin{array}{c}0.066 \\
(0.037)\end{array}$ & $\begin{array}{c}0.056 \\
(0.037)\end{array}$ & $\begin{array}{c}0.055 \\
(0.037) \\
\end{array}$ \\
\hline Year & $?$ & Yes & Yes & Yes \\
\hline \multicolumn{2}{|c|}{$\frac{1}{R^{2}}$} & 0.0736 & 0.0799 & 0.0822 \\
\hline \multicolumn{2}{|c|}{ Observations } & 3,113 & 3,113 & 3,113 \\
\hline \multicolumn{2}{|c|}{ LM test } & $1,814.32^{* * *}$ & $1,832.77^{\text {*** }}$ & $1,816.54^{\text {*** }}$ \\
\hline \multicolumn{2}{|c|}{$\mathrm{F}$ test } & $169.13^{* * * *}$ & $173.48^{* * *}$ & $174.83^{* * *}$ \\
\hline \multicolumn{2}{|c|}{ Hausman test } & $191.03^{* * *}$ & $195.30^{* * *}$ & $288.87^{* * *}$ \\
\hline
\end{tabular}

Note: 1) Levels of significance: $* p<0.05 ; * * p<0.01 ; * * * p<0.001 .2)$. Heteroscedasticityrobust standard errors are in parentheses.

Source: SORS, 2018; own calculations. 
Based on the presented empirical results, the first research hypothesis (Hypothesis 1) may be confirmed, stating that direct public support for R\&D investment in the form of $R \& D$ subsidies stimulates $R \& D$ expenditures where its specific nature makes it a less effective instrument than indirect public support in the form of $R \& D$ tax incentives. That is, a positive impact can only be confirmed for those companies which use $R \& D$ subsidies combined with $R \& D$ tax incentives, and for growing companies. Furthermore, according to the empirical results, the second research hypothesis (Hypothesis 2) is confirmed, which states that indirect public support for $R \& D$ investment in the form of $R \& D$ tax incentives stimulates $R \& D$ spending, where its general nature makes it an effective instrument for a wider population of companies.

\section{Concluding Remarks}

\subsection{Discussion and Conclusion}

This paper is focused on examining the impact of public R\&D policy on business R\&D expenditures. The results of the empirical study explain that public support for R\&D investment plays an important role in firms' R\&D spending. The empirical results suggest that $R \& D$ subsidies generally displace firms' $R \& D$ expenditures in Slovenia. Yet, the results show that R\&D subsidies become more effective when used in combination with $R \& D$ tax incentives and when growing companies receive them. On the contrary, the empirical results show that $R \& D$ tax incentives are always effective when companies have a sufficient tax base. This implies that Slovenian companies are not exploiting the potential of R\&D subsidies. This partly relates to the fact that Slovenian companies are not so familiar with R\&D subsidies. On the other hand, it seems that R\&D tax incentives are a good and effective public policy instrument that is being successfully exploited by Slovenian companies.

The reasons for the different findings on the impact of public R\&D policy on business R\&D expenditures arise from the differences in the characteristics of R\&D subsidies and R\&D tax incentives. As regards eligibility for public support, only R\&D projects with a high degree of novelty, risk or spillover capacity and meet funding-agency requirements are eligible for R\&D subsidies. On the contrary, all R\&D projects are eligible for R\&D tax incentives. Further, the magnitude of R\&D subsidies depends on their amount, which companies know in advance, while the magnitude of R\&D tax incentives depends on a company's tax position at the end of the fiscal year.

Therefore, $R \& D$ subsidies are considered as being more certain than $R \& D$ tax incentives. Finally, as concerns the timing of public support, R\&D subsidies are obtained ex ante before an $R \& D$ project starts, while $R \& D$ tax incentives are obtained ex post at the end of the fiscal year. These characteristics of R\&D subsidies do not stimulate companies towards their natural growth, which would ultimately lead to an increase in their R\&D expenditures. This implies that the effects of R\&D 
subsidies lie more in maintaining companies' business operations rather than in stimulating their growth and thus their funds for R\&D activity. On the contrary, the presented characteristics of $R \& D$ tax incentives suggest they are more growthoriented since they depend largely on a company's tax position at the end of the fiscal year. The overall conclusion is that $\mathrm{R} \& \mathrm{D}$ subsidies are used more to help companies that are growing less to maintain employment and replace older products, processes and services (unlike what is happening in companies that rely on both public policy instruments, and growing companies), while $\mathrm{R} \& \mathrm{D}$ tax incentives are used by companies with a sufficient tax base.

\subsection{Theoretical and Practical Implications}

The study results provide additional empirical support for the main theoretical foundations which are often used to explain why public support for R\&D investment is needed in a certain economy. The results reveal that public support for $R \& D$ investment contributes to reducing certain market failures by lowering the costs entailed in performing $R \& D$ activities, then allowing companies to invest more in R\&D activities. In the case of $R \& D$ subsidies, this can be confirmed for companies that use $R \& D$ subsidies and $R \& D$ tax incentives at the same time, as well as for growing companies. On the other hand, in the case of $R \& D$ tax incentives, this can be confirmed in a general sense.

The findings of this study also hold several important practical implications. The overall findings suggest that $R \& D$ tax incentives are more effective than $R \& D$ subsidies in Slovenia for the following reasons. First, the overall system in Slovenia is relatively small, fragmented (with an abundance and variety of R\&D tenders and a non-homogeneous population of companies) and two-tiered (especially since 2012 when the R\&D tax allowance rate of $100 \%$ was introduced). This implies that companies with a sufficient tax base are more inclined to $R \& D$ tax incentives since all R\&D projects funded by companies' own internal or external finances may be eligible for this form of public support for R\&D investment. On the other hand, R\&D subsidies are still attractive, especially for smaller companies without a sufficient tax base. It is hence important to consider both public policy instruments as two parallel ways of supporting firms' $R \& D$ expenditures. It is crucial that policymakers exploit the advantages and reduce the weaknesses of each instrument in order to provide public support for R\&D investment in the most efficient way.

\subsection{Limitations and Future Research}

Despite the new and interesting findings, some limitations must be recognised and future avenues for research are proposed. The first limitation is the limited research period 2012-2016 due to the need for a research period encompassing stable operating conditions for companies and a period in which both instruments of public support for R\&D investment were available in Slovenia. Accordingly, one direction for future research is to extend the research period. This may provide additional 
empirical evidence on this research topic, especially during the recent economic crisis. Second, the limited research period also makes it difficult to use sophisticated econometric approaches as they often require a longer research period to gain credible empirical results. Finally, since this study is based solely on a financial database certain important information could be overlooked. Moreover, the database used in this study lacks data on innovation outputs or related non-financial information. Given the last two limitations, it would be beneficial to conduct surveys or interviews so as to obtain non-financial information for the purposes of acquiring further insights with an emphasis on industry characteristics, something that cannot be obtained through financial data alone.

\section{References:}

Ahuja, I.P.S. 2011. Managing research and development for core competence building in an organization. Journal of technology management \& innovation, 6(1), 58-65.

Akhmetshin, E.M., Dzhavatov, D.K., Sverdlikova, E.A., Sokolov, M.S., Avdeeva, O.A., Yavkin, G.P. 2018. The influence of innovation on social and economic development of the Russian regions. European Research Studies Journal, 21, 767776.

Arkhipova, M., Sirotin, V., Afonina, V. 2019. Cooperation in R\&D as a Leading Indicator of Innovative Activity Growth. International Journal of Economics \& Business Administration, 7(Special 2), 242-257.

Arrow, K. 1962. Economic welfare and the allocation of resources for invention. In the rate and direction of inventive activity: Economic and social factors. Princeton University Press, 609-626.

Bakker, G. 2013. Money for nothing: How firms have financed R\&D-projects since the Industrial Revolution. Research policy, 42(10), 1793-1814.

Baldacchino, P.J., Portelli, J., Grima, S. 2019. The Implications and Relevance of a Tax Exemption for Co-operatives: The Case of a Small European State. International Journal of Economics \& Business Administration, 7(3), 116-132.

Bernstein, J.I. 1986. The effect of direct and indirect tax incentives on Canadian industrial R\&D expenditures. Canadian Public Policy/Analyse de Politiques, 438-448.

Bérubé, C., Mohnen, P. 2009. Are firms that receive R\&D subsidies more innovative? Canadian Journal of Economics, 42(1), 206-225.

Bloom, N., Griffith, R., Van Reenen, J. 2002. Do R\&D tax credits work? Evidence from a panel of countries 1979-1997. Journal of Public Economics, 85(1), 1-31.

Busom, I., Corchuelo, B., Martínez-Ros, E. 2014. Tax incentives... or subsidies for business R\&D? Small Business Economics, 43(3), 571-596.

Carboni, O.A. 2011. R\&D subsidies and private R\&D expenditures: evidence from Italian manufacturing data. International Review of Applied Economics, 25(4), 419-439.

Chen, M.C., Gupta, S. 2017. The incentive effects of R\&D tax credits: An empirical examination in an emerging economy. Journal of Contemporary Accounting \& Economics, 13(1), 52-68.

Coad, A., Rao, R. 2010. Firm growth and R\&D expenditure. Economics of Innovation and New Technology, 19(2), 127-145.

Curtis, A., McVay, S., Toynbee, S. 2016. Aggregate R\&D expenditures and firm-level profitability of R\&D. Working Paper, University of Washington. 
Czarnitzki, D. 2006. Research and development in small and medium-sized enterprises: The role of financial constraints and public funding. Scottish journal of political economy, 53(3), 335-357.

Dmitriev, O.N., Novikov, S.V. 2018. Transformation of Russian Tax System as Part of the Integration of the Economy into International High-Technology Production Field of Socio-economic Systems. European Research Studies Journal, 21(4), 400-413.

Dosmanbetova, A.S., Kenenova, K.A., Makenova, A.A. 2018. An Investigation into the Advisability of Using Concessional Taxation to Galvanize Innovation-Driven Economic Development. European Research Studies Journal, 21(3), 539-551.

Gashi, B., Assllani, G., Boqolli, L. 2018. The Effect of Tax Structure on Economic Growth. International Journal of Economics and Business Administration, 6(2), 56-67.

Haskel, J., Westlake, S. 2018. Capitalism without capital: the rise of the intangible economy. Princeton University Press.

Hud, M., Hussinger, K. 2015. The impact of R\&D subsidies during the crisis. Research policy, 44(10), 1844-1855.

Jin, Z., Shang, Y., Xu, J. 2018. The Impact of Government Subsidies on Private R\&D and Firm Performance: Does Ownership Matter in China's Manufacturing Industry? Sustainability, 10(7), 2205.

Jovanovic, B. 1982. Selection and the Evolution of Industry. Econometrica: Journal of the Econometric Society, 649-670.

Link, A., Scott, J. 2013. Bending the arc of innovation: Public support of R\&D in small, entrepreneurial firms. Springer.

Liu, Z. 2013. The research tax credit in the policy mix for innovation: the French case. Journal of Innovation Economics \& Management, (2), 199-223.

Meisel, J.B., Lin, S.A. 1983. The impact of market-structure on the firms allocation of resources to research and development. Quarterly Review of Economics and Business, 23(4), 28-43.

Meuleman, M., De Maeseneire, W. 2012. Do R\&D subsidies affect SMEs' access to external financing? Research Policy, 41(3), 580-591.

Min, B.S., Smyth, R. 2016. How does leverage affect R\&D intensity and how does R\&D intensity impact on firm value in South Korea? Applied Economics, 48(58), 56675675.

Nunes, P.J.M., Serrasqueiro, Z.M., Sequeira, T.N. 2009. Profitability in Portuguese service industries: a panel data approach. The Service Industries Journal, 29(5), 693-707.

Oosterbaan, M.S., van Steveninck, T.D.R., Windt, N. (Eds.). 2000. The determinants of economic growth. Kluwer Academic Publishers.

Pingfang, Z., Weimin, X. 2003. On the Impact of Government's S\&T Incentive Policy on the R\&D input and its patent output of large and medium-sized Industrial enterprises in Shanghai [J]. Economic Research Journal, 6, 45-53.

Radas, S., Anić, I. D., Tafro, A., Wagner, V. 2015. The effects of public support schemes on small and medium enterprises. Technovation, 38, 15-30.

Ravšelj, D., Aristovnik, A. 2017. R\&D Subsidies as Drivers of Corporate Performance in Slovenia: The Regional Perspective. Danube: Law and Economics Review, 8(2), 7995.

Ravšelj, D., Aristovnik, A. 2018. The Impact of Private Research and Development Expenditures and Tax Incentives on Sustainable Corporate Growth in Selected OECD Countries. Sustainability, 10(7), 2304.

Ravšelj, D., Aristovnik, A. 2019. The Impact of R\&D Accounting Treatment on Firm's Market Value: Evidence from Germany. The Social Sciences, 14(6), 247-254. 
Reifman, A., Keyton, K. 2010. Winsorize. In N.J. Salkind (Ed.), Encyclopedia of Research Design (pp. 1636-1638). Thousand Oaks, CA, Sage.

Rupeika-Apoga, R., Saksonova, S. 2018. SMEs' Alternative Financing: The Case of Latvia. European Research Studies Journal, 21(3), 43-52, DOI: 10.35808/ersj/1042.

Ryan, Jr, H.E., Wiggins III, R.A. 2002. The interactions between R\&D investment decisions and compensation policy. Financial Management, 5-29.

Solovjova, I., Rupeika-Apoga, R., Romanova, I. 2018. Competitiveness Enhancement of International Financial Centres. European Research Studies Journal, 21(1), 5-17, DOI: $10.35808 / \mathrm{ersj} / 925$.

Statistical office of the Republic of Slovenia (SORS). 2018. Microdata on R\&D activity of Slovenian companies. Ljubljana: SORS.

Takalo, T., Tanayama, T., Toivanen, O. 2013. Market failures and the additionality effects of public support to private R\&D: Theory and empirical implications. International Journal of Industrial Organization, 31(5), 634-642.

Titman, S., Wessels, R. 1988. The determinants of capital structure choice. The Journal of finance, 43(1), 1-19.

Vicente-Lorente, J.D. 2001. Specificity and opacity as resource-based determinants of capital structure: evidence for Spanish manufacturing firms. Strategic Management Journal, 22(2), 157-177.

Vokshi, N.B. 2018. The Connection between Accounting and Taxation from the Perspective of Preparing the Financial Statements. International Journal of Economics \& Business Administration, 6(4), 34-47.

Wu, A. 2017. The signal effect of Government R\&D Subsidies in China: Does ownership matter? Technological Forecasting and Social Change, 117, 339-345.

Yulianto, A.S., Chariri, A. 2019. The Role of Indonesian Tax Reform in Boosting Export Performance of Manufacturing Sectors. International Journal of Economics \& Business Administration, 7(4), 343-352. 